\title{
Circulating immune complexes in polymyalgia rheumatica and giant cell arteritis
}

\author{
J. R. PARK, J. G. JONES, G. D. HARKISS, AND B. L. HAZLEMAN \\ From Addenbrooke's Hospital, Hills Road, Cambridge CB2 $2 Q Q$
}

SUMMARY Sera from patients with giant cell arteritis and/or polymyalgia rheumatica have been found to contain increased levels of circulating immune complexes (IC). Results with the polyethyleneglycol precipitation complement consumption (PEG-CC) assay have been correlated with disease activity. $44 \%$ of samples from an active untreated group (21 patients) had increased levels of ICs compared with $23 \%$ from an inactive treated group (49 patients). Further analysis of circulating ICs was performed by ${ }^{125} \mathrm{I}-\mathrm{Clq}$ binding, the PEG-C4 test, and ${ }^{125} \mathrm{I}$-conglutinin binding assays. Although we did not find a high correlation between IC levels and disease activity, isolation and analysis of the ICs may lead to further understanding of this disorder.

Immunoglobulins and complement deposits have been demonstrated in the media and adjacent to the internal elastic lamina in some involved temporal arteries. 2 However, it is not known whether such deposits were the result of passive deposition of immune complexes (IC) from the circulation or from the combination of specific antibodies with antigens in situ. It had been noticed while screening for ICs in sera from patients with a variety of disorders that raised IC levels were detected in sera from patients with polymyalgia rheumatica (PMR)/ giant cell arteritis (GCA). These observations prompted further investigation of circulating ICs in patients with PMR/GCA.

In this paper we present the results of estimating serum immune complexes by the polyethyleneglycol precipitation complement consumption assay (PEG$\mathrm{CC}$ ) in patients with PMR/GCA. We have correlated the results with an estimate of disease activity to assess whether the measurement of ICs could assume a role in diagnosis and patient management. Additional sera have been tested by 4 independent IC assays.

\section{Materials and methods}

PATIENTS AND CONTROLS

The diagnosis of PMR and GCA were according to the criteria of Jones and Hazleman. ${ }^{2} 3$

Fifty serum samples from $28 \mathrm{PMR} / \mathrm{GCA}$ patients were tested by the PEG-CC assay as part of a

Accepted for publication 26 August 1980. Correspondence to Dr Hazleman. screening study for IC in sera from patients with a variety of disorders.

Two hundred and thirty-four serum samples from 107 patients were examined together with the clinical details, erythrocyte sedimentation rate (ESR), $\mathrm{C}$ reactive protein (CRP), and complement measurements. Four or more samples were obtained from 26 of the patients. Of the 107 patients, mean age 67 years \pm 7 (SD), 37 had PMR, 25 GCA, and 45 had both. Disease activity was assessed by one observer throughout. The symptoms of polymyalgia and of arteritis were separately graded 0-4 (inactivevery active). In an attempt to obtain an index of disease activity using both laboratory and clinical measurements the patients were subdivided into 4 groups $A-D$ (Table 1).

Table 1 Clinical and laboratory measurements used for assessment of disease activity $(A-D)$

\begin{tabular}{|c|c|c|}
\hline \multicolumn{3}{|c|}{ Disease activity } \\
\hline $\mathbf{A}$ & $\begin{array}{l}\text { Active } \\
\text { Untreated }\end{array}$ & \multirow[b]{2}{*}{$\begin{array}{l}P \text { or } T>2 \\
\text { or } E S R \gg 30 \\
\text { or } C R P \gg 16\end{array}$} \\
\hline B & $\begin{array}{l}\text { Active } \\
\text { Treated }\end{array}$ & \\
\hline C & $\begin{array}{l}\text { Slightly active } \\
\text { Treated }\end{array}$ & $\begin{array}{l}P \text { or } T \gtrless 1 \\
\text { ESR } ₹ 29 \\
\text { CRP } ₹ 15\end{array}$ \\
\hline D & No activity & $\begin{array}{l}\text { PT 0, } 0 \\
\text { ESR } ₹ 20 \\
\text { CRP } ₹ 6\end{array}$ \\
\hline \multicolumn{2}{|c|}{$\begin{array}{l}\mathbf{P}=\text { Symptoms of polymyalgia } \\
\mathbf{T}=\text { Symptoms of temporal arteritis }\end{array}$} & \} $\begin{array}{l}\text { Graded } 0-4 \\
\text { (inactive-very active). }\end{array}$ \\
\hline
\end{tabular}


The PEG-CC, PEG-C4, and ${ }^{125}$ I-Clq binding IC assays were used to study 2 patients serially and 74 serum samples from 24 patients were tested by the PEG-CC, ${ }^{125} \mathrm{I}-\mathrm{Clq}$ binding, and ${ }^{125} \mathrm{I}$-conglutinin binding IC assays. Normal human sera obtained from the National Blood Transfusion Service (NBTS) in Cambridge were used to establish the normal ranges. Also 30 sera from healthy people age $>50$ years (mean $58 \pm 5$ ) were tested in the PEG-CC assay. Blood samples from the patients and controls were clotted at room temperature and the sera were stored at $-20^{\circ} \mathrm{C}$ within 3 hours of collection. An aliquot was stored in liquid nitrogen for complement studies.

\section{METHODS}

Immune complexes were measured by the PEG-CC test as described by Harkiss and Brown. ${ }^{4}$ In this test IC are first precipitated from serum with $2.5 \%$ polyethyleneglycol (PEG), and the precipitate is redissolved in complement fixing diluent to $1 / 10$ the original volume of serum. Residual complement fixing ability is then assayed in a sensitive complement consumption procedure. The results are expressed as 'percentage complement consumption' (\%CC).

ICs were measured by the $\mathrm{C} 4$ test described by Digeon et al. ${ }^{5} \mathrm{C} 4$ bound to IC is precipitated from serum with $3 \%$ PEG and then assayed by radial immunodiffusion.

${ }^{125} \mathrm{I}$-Clq binding ICs were measured by the method of Zubler et al. ${ }^{6}$

${ }^{125}$ I-conglutinin binding was measured by the method of Macanovic and Lachmann. ${ }^{7}$ Conglutinin, a protein found only in bovine serum, has a calciumdependent specificity for IC that have fixed complement in vivo and have bound $\mathrm{C} 3 \mathrm{bi}$.
Immunoglobulin levels of serum samples were determined by single radial immunodiffusion.

Total haemolytic complement $\left(\mathrm{CH}_{50}\right)$ was measured by the kinetic turbimetric assay described by Lachmann and Hobart. ${ }^{8}$ The thrid component of complement (C3) was measured by rocket immunoelectrophoresis.

Normal ranges were established from the mean \pm 2 standard deviations. For the IC assays they were: PEG-CC 0-24\%, PEG-C4 0-1.29 mg/100ml, ${ }^{125} \mathrm{I}-\mathrm{Clq}$ binding $0 \cdot 8-5 \cdot 6 \%,{ }^{125} \mathrm{I}$-conglutinin binding $0-18.6 \%$. The normal ranges for complement were: $\mathrm{CH}_{50}$ 900-1800 units/ml, C3 60-180 mg/dl (SI conversion: $\mathrm{mg} / \mathrm{l}=\mathrm{mg} / 100 \mathrm{ml}(\mathrm{dl}) \times 10$.)

\section{Results}

Fifteen of the initial 28 patients $(54 \%)$ in the screening study were shown to have raised immune complex levels when tested by the PEG-CC assay (Table 2). Results of assaying sera from patients with other disorders for IC by the PEG-CC test are included for comparison. Analysis of the results by the Mann-Whitney $U$ rank correlation test indicated that the PMR/GCA IC levels were significantly different (mean $21 \pm 13$ ) from the NBTS controls (mean $14 \pm 5$ ) and suggested further study.

In the sera from a further 107 patients $50(47 \%)$ were shown to have raised IC at some time. This represented $32 \%$ of the samples tested (mean $22 \pm$ 20 ) and confirmed the finding of $32 \%$ samples showing raised IC in the screening study. In contrast, raised IC levels were seen in only 2 of $30(7 \%)$ samples from the controls aged 50 years or over and 56 of $94(60 \%)$ samples from rheumatoid arthritis patients at different stages of their disease.

Fig. 1 shows the IC levels when the PMR/GCA

Table 2 Incidence of circulating immune complexes in sera from patients with various diseases (PEG-CC assay)

\begin{tabular}{|c|c|c|c|c|c|c|}
\hline Disease & $\begin{array}{l}\text { Number of } \\
\text { patients }\end{array}$ & $\begin{array}{l}\text { Number of } \\
\text { patients above } \\
\text { normal at } \\
\text { least once }(\%)\end{array}$ & $\begin{array}{l}\text { Number* } \\
\text { of samples }\end{array}$ & $\begin{array}{l}\text { Number of } \\
\text { samples above } \\
\text { normal }(\%)\end{array}$ & $\begin{array}{l}\% \mathrm{CC} \\
\text { mean } \pm \\
S D\end{array}$ & $\begin{array}{l}\text { Statistical } \\
\text { significance } \\
\text { (Mann-Whitney } U \text { ) }\end{array}$ \\
\hline $\begin{array}{l}\text { Systemic lupus erythematosus } \\
\text { Rheumatoid arthritis } \\
\text { Post-streptococcal glomerulonephritis } \\
\text { Infective endocarditis } \\
\text { Idiopathic vasculitis } \\
\text { Erythema nodosum } \\
\text { Purpura } \\
\text { Primary biliary cirrhosis } \\
\text { Renal transplantation } \\
\text { Polymyalgia rheumatica/giant cell arteritis } \\
\text { Polyarthritis of unknown origin } \\
\text { Ulcerative colitis } \\
\text { Crohn's disease } \\
\text { Normal controls }\end{array}$ & $\begin{array}{r}53 \\
50 \\
14 \\
7 \\
28 \\
10 \\
14 \\
8 \\
57 \\
28 \\
65 \\
43 \\
36 \\
54\end{array}$ & $\begin{array}{c}32(60) \\
30(60) \\
11(79) \\
7(100) \\
11(39) \\
5(50) \\
5(36) \\
7(88) \\
29(51) \\
15(54) \\
18(28) \\
6(18) \\
2(6) \\
0(0)\end{array}$ & $\begin{array}{r}192 \\
89 \\
34 \\
25 \\
36 \\
15 \\
15 \\
10 \\
222 \\
50 \\
73 \\
50 \\
37 \\
54\end{array}$ & $\begin{array}{c}107(56) \\
43(48) \\
19(56) \\
16(64) \\
16(44) \\
7(47) \\
5(30) \\
8(80) \\
70(32) \\
16(32) \\
19(26) \\
8(16) \\
2(5) \\
0(0)\end{array}$ & $\begin{array}{l}43 \pm 69 \\
36 \pm 66 \\
44 \pm 40 \\
36 \pm 24 \\
29 \pm 25 \\
33 \pm 29 \\
24 \pm 14 \\
29 \pm 7 \\
22 \pm 17 \\
21 \pm 13 \\
21 \pm 18 \\
20 \pm 31 \\
12 \pm 9 \\
14 \pm 5\end{array}$ & $\begin{array}{l}p<0.001 \\
p<0.001 \\
p<0.001 \\
p<0.001 \\
p<0.001 \\
p<0.001 \\
p>0.1 \\
p<0.001 \\
p<0.002 \\
p<0.05 \\
p<0.05 \\
p>0.1 \\
p>0.1\end{array}$ \\
\hline
\end{tabular}

*Includes samples obtained from patients during convalescence or remission. 


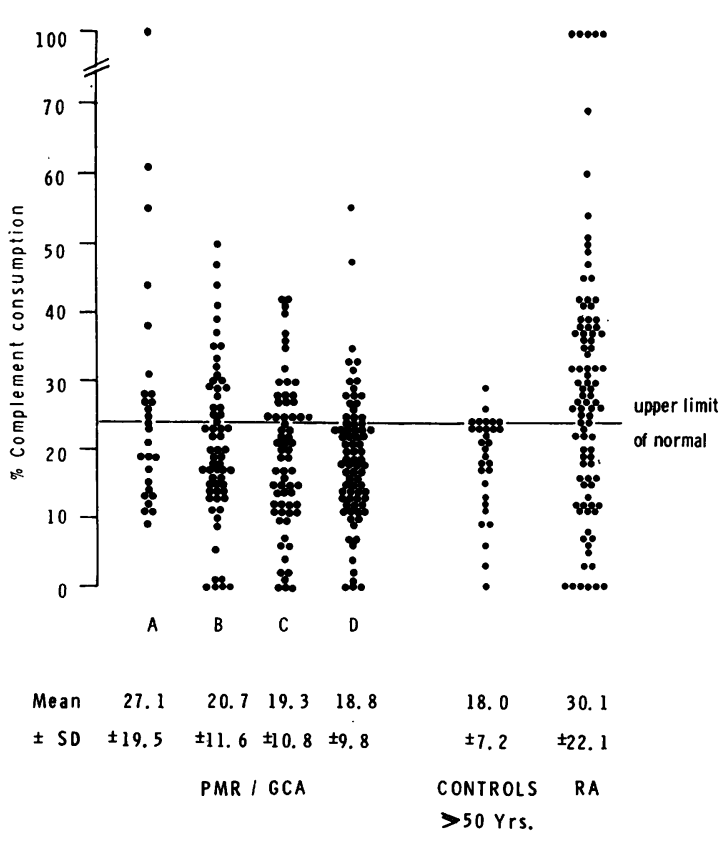

Fig. 1 Immune complex levels $(P E G-C C)$ at different stages of disease activity in $107 \mathrm{PMR} / G C A$ patients, controls aged 50 years or over and rheumatoid arthritis patients.

patients were separated into groups with different disease activity (A-D). Twelve of $27(44 \%)$ samples in the active untreated group A (27 patients) had increased levels of IC compared with 18 of $78(23 \%)$ samples in the inactive group D (49 patients). The immune complex results of the controls aged 50 years or over and the rheumatoid arthritis patients are also shown. The Mann-Whitney $U$ test showed a statistically significant difference between the active group $A$ and the inactive group $D(p<0.04)$ as well as between group $A$ and the controls aged 50 years or over $(p<0 \cdot 04)$. There was a significant difference between the combined active disease groups A and B and the combined groups with no or little disease activity (C and D) $(\mathrm{p}<0 \cdot 05)$. However, there was no statistically significant difference between those samples from patients with some disease activity (groups $\mathrm{A}, \mathrm{B}$, and $\mathrm{C}$ ) and those with no activity (group D).

Table 3 subdivides the PMR/GCA groups A-D into those with or without clinical evidence of arteritis at some time during the course of their disease. Complexes were more frequently raised in samples from patients who had clinical evidence of arteritis at some stage, although the difference in IC
Table 3 Number of samples with raised (PEG-CC) immune complex levels at different stages of disease activity according to past or present history of clinical arteritis

\begin{tabular}{lccc}
\hline $\begin{array}{l}\text { Past or present history of } \\
\text { clinical arteritis }\end{array}$ & $\begin{array}{l}\text { Number of samples }>24 \% \\
\text { complement consumption }\end{array}$ \\
\hline A & + & $8 / 15$ & $53 \%$ \\
& - & $4 / 12$ & $33 \%$ \\
B & + & $16 / 44$ & $36 \%$ \\
& - & $5 / 18$ & $28 \%$ \\
C & + & $18 / 55$ & $33 \%$ \\
& - & $4 / 11$ & $36 \%$ \\
D & + & $11 / 51$ & $22 \%$ \\
\hline
\end{tabular}

levels did not reach statistical significance by the chi-square test.

The results of serial studies with three IC assays in 2 patients before and after treatment with prednisone are shown in Figs. 2 and 3. In one of these patients (Fig. 2) 2 sera taken before treatment showed raised IC levels by all 3 assays. Subsequently PEG-CC and ${ }^{125} \mathrm{I}-\mathrm{Clq}$ binding IC levels returned to within the normal ranges, though the PEG-C4 IC levels remained raised. In the other patient (Fig. 3) IC levels were raised before treatment, and, while PEG-CC and PEG-C4 IC levels fell, as did the ESR, with treatment, ${ }^{125} \mathrm{I}-\mathrm{Clq}$ binding IC was only within the normal range intermittently. While in some of the 107 patients PEG-CC IC levels were raised before treatment and then fell towards normal on treatment, in others no relationship was evident. ESR measurements on the other hand were invariably raised before treatment and subsequently dropped to normal.

Seventy-four serum samples from a third series of 24 PMR/GCA patients were investigated for IC by the PEG-CC, ${ }^{125}$ I-Clq binding, and ${ }^{125} \mathrm{I}$-conglutinin binding assays (Table 4). Analysis of the results by the Spearman rank correlation test showed a correlation between the ${ }^{125} \mathrm{I}$-conglutinin binding and the ${ }^{125} \mathrm{I}-\mathrm{Clq}$ binding assay $(\mathrm{r}=0.32, \mathrm{p}<0.03)$. A lower

Table $4 P E G-C C,{ }^{125} I-C l q$ binding, and ${ }^{125} I$-conglutinin binding immune complex levels in 74 sera from PMR/GCA patients

\begin{tabular}{llcc}
\hline IC Assay & $\begin{array}{l}\text { No. of } \\
\text { samples }\end{array}$ & $\begin{array}{l}\text { Samples above } \\
\text { normal range }\end{array}$ & $\%$ \\
\hline PEG-CC & 72 & 18 & 25 \\
125I-Clq binding & 41 & 11 & 27 \\
125I-conglutinin binding & 74 & 5 & 7 \\
\hline
\end{tabular}

Twelve samples taken during active untreated disease. 


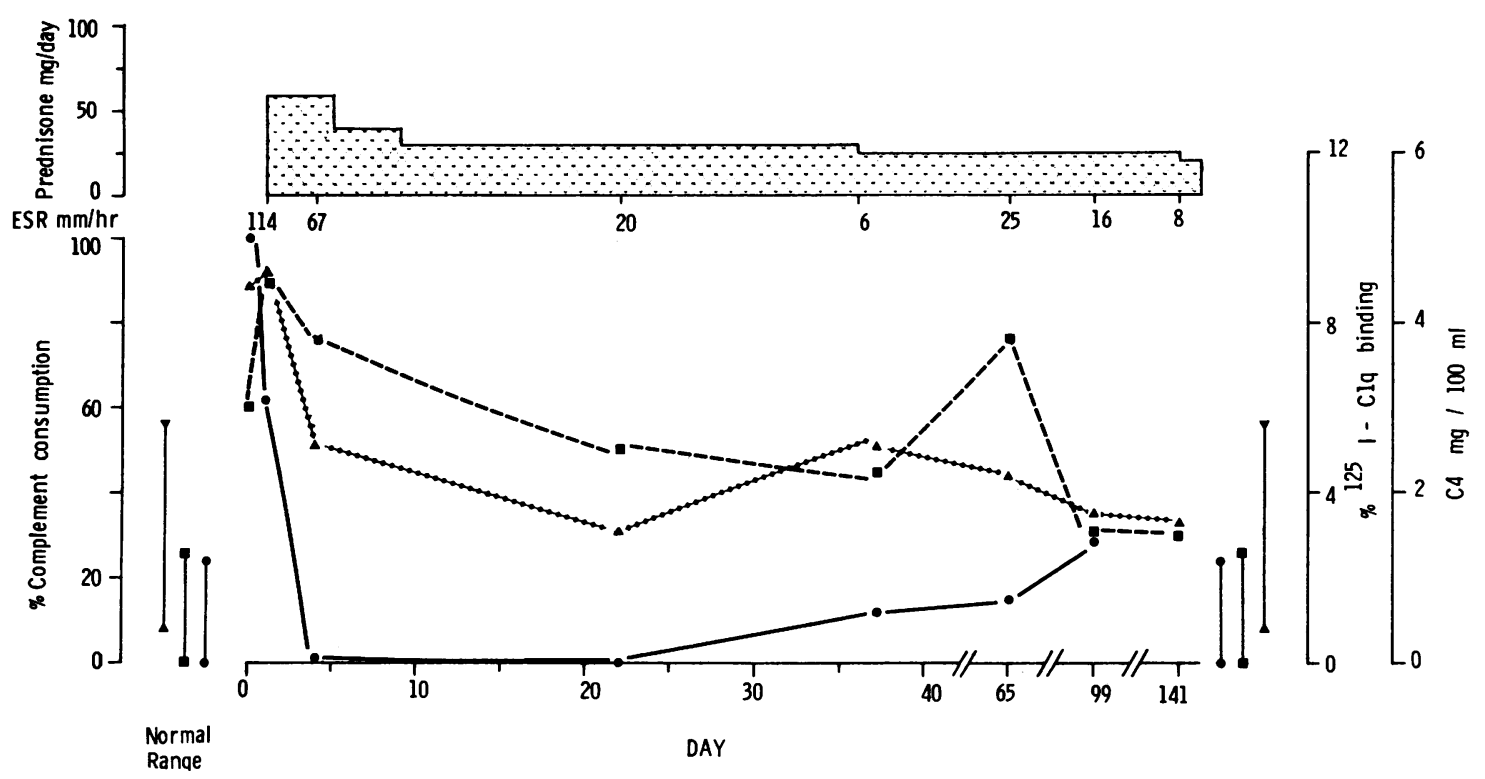

Fig. 2 Serial immune complex levels $\left(\bullet-\bullet P E G-C C, \triangle \bullet \cdot \bullet-\bullet-\bullet{ }^{125} I-C l q\right.$ binding, ESR in a patient with giant cell arteritis.

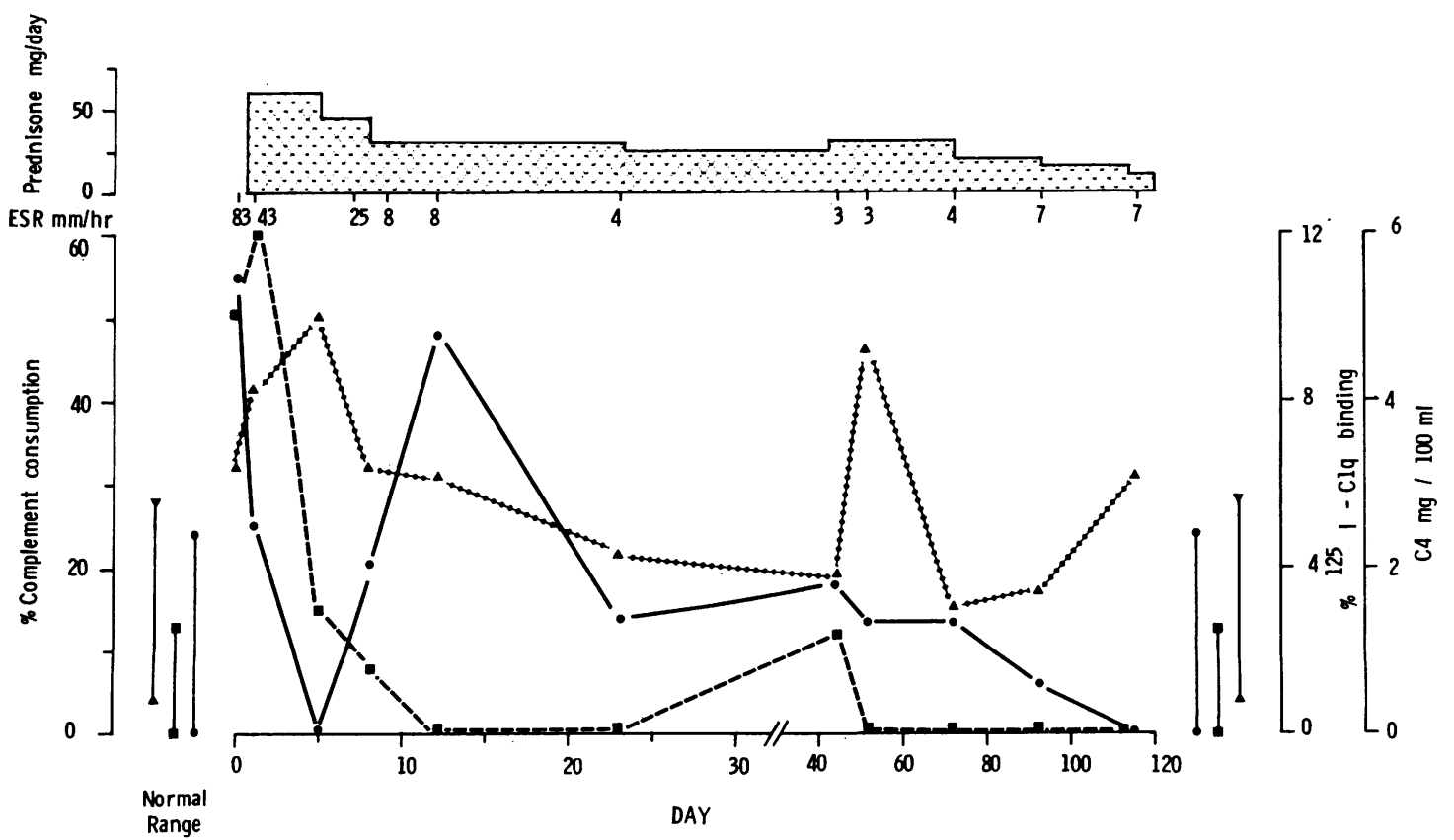

Fig. 3 Serial immune complex levels ( $P E G-C C$, ${ }^{125}$ I-Clq binding, 
correlation was shown between the PEG-CC and ${ }^{125} \mathrm{I}$-conglutinin binding assays $(\mathrm{r}=0 \cdot 21, \mathrm{p}<0 \cdot 05)$, but the PEG-CC showed no significant correlation with the ${ }^{125} \mathrm{I}-\mathrm{Clq}$ binding assay $(\mathrm{r}=-0 \cdot 08, \mathrm{p}>0 \cdot 1)$. However, of the 18 samples abnormal in the PEG-CC assay 6 were also abnormal by the ${ }^{125} \mathrm{I}$-Clq binding assay, but only 1 of the 18 samples was also abnormal by the ${ }^{125}$ I-conglutinin binding assay. A total of 27 of $74(37 \%)$ samples were abnormal by a combination of all 3 assays.

Determinations of complement levels show that both the total haemolytic complement and $\mathrm{C} 3$ values were within normal levels. Immunoglobulins were found to be raised in both the active and inactive group. In the active group more than one immunoglobulin was often raised in the same patient, and 18 out of 39 patients in all had raised immunoglobulins.

The Spearman rank correlation test was used to assess correlation between different measurements. There is no significant correlation between the levels of PEG-CC immune complexes and complement $\mathrm{CH}_{50}(\mathrm{r}=-0.03, \quad \mathrm{p}>0.05), \quad$ ESR $(\mathrm{r}=0.11$, $p>\cdot 0.05)$, CRP $(r=0.05, p>0.05)$ and a low negative correlation with $\mathrm{C} 3(\mathrm{r}=-0 \cdot 16, \mathrm{p}<0 \cdot 05)$.

\section{Discussion}

Immune complexes above the normal range have been demonstrated in sera from PMR and GCA patients by the PEG-CC, PEG-C4, and ${ }^{125} \mathrm{I}-\mathrm{Clq}$ binding assays though not by the ${ }^{125} \mathrm{I}$-conglutinin binding test.

The IC assays employed in the serial studies showed similar patterns of increased IC levels during active disease and normal levels at inactive stages of the disease; this paralleled the fall in ESR on treatment with prednisone. However, correlations between the IC assays do not reflect the results of comparing IC levels with the normal ranges. The differences in results between the IC assays probably reflect their abilities to detect ICs which are heterogeneous in respect of size, immunoglobulin class, and complement fixing ability. ${ }^{9}$ Delespesse et al. ${ }^{10}$ have reported an increase in IC levels with age as measured by ${ }^{125} \mathrm{I}-\mathrm{Clq}$ binding. However, only 2 sera from 30 controls aged 50 years or over tested by the PEG-CC assay fell outside the normal range. Although these ages were not as high as those of the PMR/GCA patients, the small proportion of results above the normal range suggests that age is not a significant factor in producing the raised IC values in PMR/ GCA patients.

PEG-CC IC levels during active and inactive disease showed a significant difference, though this was not confirmed statistically when the presence or absence of arteritis (diagnosed clinically) was used.
Low levels of IC were present during inactive stages of the disease: this is not confined to PMR/GCA patients and is found in patients with systemic lupus erythematosus and rheumatoid arthritis. ${ }^{11} 12$ The possibility that the increased reactivity in PMR/GCA sera found with the PEG-CC test was due to interference by raised CRP levels has previously been discounted, ${ }^{4}$ and is confirmed here, since no correlation was found between PEG-CC, IC, and CRP levels and 2 other assays independently show raised IC values. The presence or absence of IC also depends to some extent on the type and intensity of drug therapy applied. Thus, high levels of steroids may have immunosuppressive as well as antiinflammatory properties, and these may cause a marked reduction in antibody production and hence in IC levels. On the other hand, lower dose steroid therapy may be sufficiently anti-inflammatory to maintain suppression of clinical activity but insufficiently immunosuppressive to reduce IC formation completely. Alternatively, the poor correlation between disease activity and the presence of circulating immune complexes may reflect the difficulty of objectively measuring disease activity in PMR/GCA.

Immune deposits in the artery wall together with antiglobulin activity, ${ }^{13}$ inflammatory cell infiltration, ${ }^{14}$ and increase in circulating immunoblast levels ${ }^{15}$ have already been demonstrated in patients with PMR and GCA. The presence of raised levels of IC lends further support to the hypothesis that there is an immunological component to these diseases. However, the finding of immune deposits in affected tissue, commonly thought to indicate IC induced disease, are also found in diseases where there is little else to suggest IC disease. ${ }^{16}$ The modest increase in ICs without alteration in complement levels, unlike the situation in SLE, together with the absence of other serological abnormalities and the chronic granulomatous appearance of the inflammatory lesion in the involved vessels, are also not typical of immune complex mediated disease process. ${ }^{17}$

We have demonstrated the presence of circulating ICs in the serum from patients with PMR/GCA during both active and inactive stages of the disease. However, it is not known whether these ICs are relevant to this disease process. Studies to establish the nature of the ICs, both circulating and as immune deposits, and in particular the antigen they contain, could further our knowledge of the aetiology of GCA. However, the ICs detected in this study do not suggest that their routine measurement will aid diagnosis or management of the condition.

We thank the Arthritis and Rheumatism Council for its continued support, and the physicians at Addenbrooke's Hospital who referred patients to us. 


\section{References}

1 Liang G C, Simkin P A, Mannik M D. Immunoglobulins in temporal arteries. Ann Intern Med 1974; 81 : 19-24.

2 Park J R, Hazleman B L. Immunological and histological studies of temporal arteries. Ann Rheum Dis 1978; 37: $238-43$.

3 Jones J G, Hazleman B L. The prognosis and management of polymyalgia rheumatica (PMR). Ann Rheum Dis in press.

4 Harkiss G D, Brown D L. Detection of immune complexes by a new assay, the polyethyleneglycol precipitationcomplement consumption test (PEG-CC). Clin Exp Immunol 1979; 36: 117-29.

5 Digeon M, Laver M, Riza J, Bach J F, Detection of circulating immune complexes in human sera by simplified assays with polyethyleneglycol. J Immunol Methods 1977; 16: 165-83.

6 Zubler R H, Lange G, Lambert P H, Miescher P A. Detection of immune complexes in unheated sera by a modified ${ }^{125}$ I-Clq binding test. J Immunol 1976; 116: $232-5$.

7 Macanovic M, Lachmann P J. Conglutinin binding polyethyleneglycol precipitation assay for immune complexes. Clin Exp Immunol 1979; 38: 274-83.

${ }^{8}$ Lachmann P J, Hobart M. Complement technology. In: Weir D M, ed. Handbook of Experimental Immunology. 2nd ed. Oxford: Blackwell, 1973: chapter 5.

9 Levinsky R J, Soothill J S. The heterogeneity of immune complexes in disease. In: Peters $\mathrm{H}$, ed. Protides of the Biological Fluids. Proceedings of the twenty-sixth colloquium Oxford: Pergamon Press, 1978: 243-6.
10 Delespesse G, Gausset P H, Sarfati M, Dubi-Rucquoy M, Debisschop M J, Van Haelst $L$. Circulating immune complexes in old people and in diabetics: correlation with autoantibodies. Clin Exp Immunol 1980; 40: 96-102.

11 Harkiss G D, Hazleman B L, Brown D L. A longitudinal study of circulating immune complexes, DNA antibodies and complement in patients with systemic lupus erythematosus: an analysis of their relationship to disease activity. J Clin Lab Immunol 1979; 2: 275-83.

12 Erhardt C C, Mumford P, Maini R N. The association of cryoglobulinaemia with nodules, vasculitis and fibrosing alveolitis in rheumatoid arthritis and their relationship to serum $\mathrm{Clq}$ binding activity and rheumatoid factor. Clin Exp Immunol 1979; 38: 405-13.

13 Waaler E, Tonder O, Milde E-J. Immunological and histological studies of temporal arteries from patients with temporal arteritis and/or polymyalgia rheumatica. Acta Pathol Microbiol Scand (sect. A) 1976; 84: 55-63.

14 Ainsworth R W, Gresham G A, Balmforth G V. Pathological changes in temporal arteries removed from unselected cadavers. J Clin Pathol 1961 ; 14: 115-9.

15 Eghtedari A A, Esselinck W, Bacon P A. Circulating immunoblasts in polymyalgia rehumatica. Ann Rheum Dis 1976; 35: 158-62.

16 Sutherland J C, Mackham R V, Mardiney M R. Subclinical immune complexes in the glomeruli of kidneys post mortem. Am J Med 1974; 57: 536-41.

17 Cochrane C G, Koffler D. Immune complex disease in experimental animals and man. $A d v$ Immunol 1973; 16: 185-264. 